\title{
Uma campanha política para uma eleição que não aconteceu: as práticas propagandísticas dos integralistas em Garanhuns-PE (1936-1937)
}

\section{A political campaign for an election that never happened: the propaganda practices of the integralists in the municipality of Garanhuns, state of Pernambuco (1936-1937)}

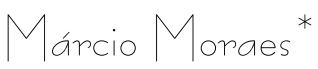

Este artigo propõe discutir alguns aspectos da campanha presidencial de Plínio Salgado pelo partido da Ação Integralista Brasileira (AIB) na cidade de Garanhuns-PE, entre os anos de 1936 e 1937. Para a realização dessa pesquisa, escolhemos como norte os pressupostos defendidos pelo que se convencionou chamar de Nova História Política. Diferenciando-se da tradicional História Política, em que a partir de uma perspectiva macro-histórica, os eruditos teciam narrativas em busca de uma "verdade absoluta", tendo geralmente como fios condutores os feitos de heróis e personalidade politicas. Os novos trabalhos de história, que se voltam para as relações de poder e disputas políticas, procuram ampliar as possibilidades de discussões, inovando com a escolha de objetos de análise e aumentando o leque de fontes documentais utilizadas. ${ }^{1}$

\footnotetext{
" Mestre em História pela Universidade Federal Rural de Pernambuco. E-mail: marcioammoraes@hotmail.com

1 Ângela de Castro Gomes, no artigo Política: história, ciência, cultura e etc, apresenta um panorama do desenvolvimento dos estudos políticos nos centros acadêmicos brasileiros, contribuindo assim na compreensão de como novos temas, fontes e abordagens começaram a ser produzidas no decorrer do século XX. Cf. GOMES, Ângela de Castro. Política: história, ciência, cultura e etc. Estudos Históricos - Historiografia. Rio de Janeiro, v.9, n. 17, p.59-84, 1996.
} 
Apresentar outras vias de estudos sobre as relações políticas tornou-se então o grande desafio. O livro Por uma História Política, organizado por René Remond, apresenta uma coletânea de textos de renomados pesquisadores, que apontam novas possibilidades de análises, como o caso das eleições, formação de partidos políticos e ideologias, propaganda, biografia, opinião pública, intelectuais, guerra, dentre outros assuntos. ${ }^{2}$ Além disso, mantendo em sua prática diálogos com outras áreas do saber, como observou Marieta de Moraes Ferreira, o historiador do político desenvolve seu trabalho utilizando-se da ciência politica, antropologia, sociologia, analistas do discurso dentre outros. ${ }^{3}$ No caso deste artigo, buscaremos ver como as estratégias propagandísticas de membros do integralismo do interior pernambucano buscaram construir uma imagem pública positiva para o seu candidato e outra, marcada por estigmas negativos, para os seus oponentes.

A AIB foi um movimento político e ideológico que, durante os anos 1930, ocupou um lugar de destaque no cenário nacional. Respeitados por grupos tradicionais da sociedade brasileira, os integralistas apresentavam uma estrutura paramilitar, com insígnias do Sigma $(\Sigma)^{4}$, saudações como Anauê $\hat{e}^{5}$, fardamentos, desfiles e outros elementos que compunham o seu universo simbólico. Além de seus discursos de caráter nacionalista e conservador, alicerçados em pressupostos cristãos que atraíram milhares de brasileiros para as fileiras integralistas.

Outro assunto que vai perpassar esse trabalho é a relação entre o político e o sentimental. Segundo o historiador Pierre Ansart, não há como separar os interesses e escolhas politicas das paixões, ressentimentos, ódios e medos dos envolvidos nas

${ }^{2}$ Cf.: RÉMOND, René. Por uma História Política. 2 ed. Rio de Janeiro: Editora FGV, 2003.

${ }^{3}$ Cf.: FERREIRA, Marieta de Moraes. A nova "velha História": o retorno da História Política. Estudos Históricos, Rio de Janeiro, vol. 5, n.10, p.265-271, 1992, p. 265. Disponível em: <http://bibliotecadigital.fgv.br/ojs/index.php/reh/article/viewArticle/1937>. Acesso em: 10 jan. 2012. Em nosso caso, como se perceberá no decorrer do texto, buscamos manter diálogo com Michel Foucault e pensadores da Análise do Discurso Francês.

${ }^{4}$ Símbolo que representa a somatória em matemática e que era utilizado pelos membros da AIB para evidenciar a união do povo brasileiro em torno do ideal integralista de implantação do Estado Integral, que estaria alicerçado no lema: Deus, Pátria e Família. Cf. BARROSO, Gustavo. O que o Integralista deve saber. 2. ed. Rio de Janeiro: Civilização Brasileira S/A., 1935.

${ }^{5}$ Significa em Tupi: "Você é meu irmão". Ibidem. 
disputas por poder. ${ }^{6}$ Esse autor contribuiu com nossas análises em relação às práticas doutrinárias do integralismo, pois esse movimento procurou nutrir, entre os seus membros, sentimentos variados envolvendo desde o orgulho advindo de pertencer a um grupo de caráter nacional até a sensação de acreditarem serem os defensores dos pressupostos religiosos do cristianismo entre os brasileiros. A propaganda da AIB incutia nos militantes a ideia de que eles eram soldados da pátria lutando contra os inimigos nacionais e da fé cristã (judeus, maçons, liberais-democratas e comunistas).

Mesmo apresentando-se como opositor ao sistema democrático - discursado por Salgado e seus seguidores como uma organização política ineficiente e voltada a defender os interesses de uma elite econômica -, os integralistas perceberam que a melhor forma de chegar à liderança do país estava na eleição presidencial, marcada para 03 de janeiro de 1938. Ainda que para chegar ao poder tivessem que enfrentar outras personalidades políticas com maior aceitação entre os eleitores brasileiros. No caso, os candidatos Armando Sales de Oliveira e José Américo de Almeida, oposicionistas de Salgado na corrida pela presidência do país. Nesse momento, como aparece nas páginas dos jornais da época, havia uma grande expectativa em torno de qual elegivel substituiria o gaúcho Getúlio Vargas, que estava no comando desde o golpe de 1930.

A nossa investigação encontrou seus sujeitos em solo pernambucano, mais especificamente na Garanhuns dos anos 1930. Esse município localizado no agreste do estado encontrase incrustado no Planalto da Borborema, envolvido por serras que marcam seu clima ameno no verão e de baixas temperaturas no inverno, com média anual entre 13 e $21^{\circ} \mathrm{C}$. Sensação térmica incomum no nordeste brasileiro, onde predominam as secas e elevadas temperaturas. Nas primeiras décadas do século passado, a referida cidade destacava-se entre as suas vizinhas, isso por causa da produção de café e do crescente comércio, que tinha na Av. Santo Antônio o seu cerne financeiro.

${ }^{6}$ Cf.: ANSART, Pierre. História e memória dos ressentimentos. BRESCIANI, Stella; NAXARA, Márcia. Memória e (res)sentimento: indagações sobre uma questão sensível. Campinas, SP: Editora da Unicamp. 2004, p. 15-35. 
O integralismo instalou-se oficialmente na referida cidade em 1935, depois de receber a caravana ou como era chamada uma Bandeira, intitulada de 07 de Outubro, formada por estudantes da Faculdade de Direito do Recife. ${ }^{7}$ Esses bacharéis da capital tornar-se-iam os referenciais dos integralistas garanhuenses. A doutrina do Sigma, como eram chamados os ensinamentos da AIB, levava algumas vantagens na propaganda política, pois os discursos de cunho anticomunista de membros da Igreja Católica e do governo Vargas se encarregavam de dar poder de recepção aos discursos dos camisas-verdes (como também eram chamado os membros da AIB) e ao modelo administrativo apresentado por eles. ${ }^{8}$

Dentro de pouco tempo de atuação na cidade, os integralistas começaram a modificar as relações políticas e a produzir novas tensões sociais. Não mais as famílias oligárquicas disputavam espaço entre si ou com os correligionários locais de Getúlio Vargas, mas a partir de 1935, os jovens vestidos com a farda verde da AIB começaram a se declarar inimigos dos liberais-democratas e dos comunistas, ambos identificados no discurso dos seguidores de Salgado como posturas ideológicas exóticas e perniciosas ao povo brasileiro. Os principais militantes garanhuenses foram homens e mulheres que exerceram atividades profissionais como médicos, dentistas, farmacêuticos, advogados, professores, funcionários públicos, comerciantes, estudantes e pequenos proprietários de terras. Diferenciando-se dos outros núcleos integralistas do interior

\footnotetext{
${ }^{7}$ Sobre o envolvimento de alguns membros da Faculdade de Direito do Recife, ver: SILVA, Giselda Brito. A Ação Integralista Brasileira em Pernambuco (1932-1937). Recife: UFPE, 1996. 130 f. Dissertação (Mestrado em História). UFPE/CFCH, Recife, 1996; e MOURA, Carlos André Silva de. Fé, saber e poder: os intelectuais entre a Restauração Católica e a política no Recife (1930 -1937). Recife, UFRPE, 161 f. Dissertação (Mestrado em História). Programa de Pós-Graduação em História Social da Cultura/ UFRPE. Recife, 2010.

${ }^{8}$ Nesse momento, lembramo-nos de uma observação feita por Michel Foucault: “[...] suponho que em toda sociedade a produção discursiva é ao mesmo tempo controlada, selecionada, organizada e redistribuída por certo número de procedimentos que têm por função conjurar seus poderes e perigos [...]" (FOUCAULT, Michel. A Ordem do Discurso: aula inaugural no Collège de France, pronunciada em 2 de Dezembro de 1970. 11 ed. São Paulo: Loyola, 2004, p. 8-9). Desse modo, a escolha do que dizer e para quem e como se produzir um discurso, chamou nossa atenção, pois a escolha do inimigo social (o comunista) para os militantes da AIB em Garanhuns deu-se provavelmente porque o perigo comunista possuía um impacto maior entre os leitores do jornal do que as disputas com grupos políticos tradicionais da cidade.
} 
pernambucano, marcados pela liderança e financiamento das famílias oligárquicas. ${ }^{9}$

Entretanto, apesar do momento ser receptivo aos discursos integralistas, pautados em preceitos cristãos e nacionalistas, nem todos os moradores da cidade receberam passivamente a propaganda da AIB. Ocorreram embates com outros grupos - destacaremos aqui os membros da loja maçônica O Mensageiro do Bem - e ainda os jovens enfrentaram as desconfianças de algumas famílias locais. Por outro lado, a presença desses militantes do Sigma nas ruas contribuiu para que houvesse um palco de grandes agitações, por ocasião da proximidade da eleição que deveria ocorrer em janeiro de 1938, onde os camisas-verdes e simpatizantes sonhavam e discursavam sobre uma possivel vitória nas urnas de Plínio Salgado.

\section{A caminho das urnas: a campanha eleitoral dos integralistas em Garanhuns para uma eleição que não aconteceu (1936-1937)}

O fervilhar e o agito das eleições marcavam as páginas dos jornais do municipio de Garanhuns, indicando, assim, que os grupos politicos locais estavam envolvidos na organização das campanhas presidenciais dos três e, por causa disso, cada vez mais palavras "ásperas" eram direcionadas aos seus adversários, aumentando os conflitos sociais e ressentimentos entre os correligionários dos candidatos. Desse modo, por meio de palestras ministradas no núcleo ou em outros espaços da cidade, além da distribuição de panfletos e da prática de escrita do seu periódico, A Razão, os integralistas procuraram divulgar e convencer seus conterrâneos de que Plínio Salgado era o melhor nome para comandar o país.

Nesse momento, a Constituição Brasileira de 1934, escrita após os levantes de cunho constitucionalistas no estado de São Paulo, no ano de 1932, marcava o fim da primeira experiên-

\footnotetext{
${ }^{9}$ Cf. SILVA, G. 1996. 79. Além dessa obra, em nossa prática de pesquisa, conseguimos levantar uma documentação que corrobora com essa formação social da AIB em Garanhuns. Como pode ser visto em: MORAES, Márcio André Martins de. Garanhuns sob o símbolo do sigma: o cotidiano dos integralistas entre comunistas e o Estado Novo (1935-1942). 2012. 215f. Dissertação (Mestrado em História). Programa de Pós-Graduação em História Social da Cultura Regional/ UFRPE, Recife.
} 
cia administrativa de tendências autoritárias de Getúlio Vargas, que desde o golpe de 1930 governava a partir de decretos e sem a interferência do poder legislativo e de partidos oposicionistas. Mesmo dando um passo em direção à caminhada da democratização do Brasil, Vargas continuou como líder do poder executivo do país depois de uma votação indireta. Mas essa situação deveria, ao menos na teoria, mudar em janeiro de 1938, quando um novo presidente seria escolhido pelo voto popular.

As novas experiências democráticas no país teriam como marco inicial as eleições municipais de 1935 que inovavam com o voto secreto e a inclusão do sufrágio feminino. Esse "ensaio democrático" deveria contribuir na formação de uma atmosfera favorável para a escolha política a nivel estadual e federal, marcada para 1938. Ao mesmo tempo em que o povo tinha readquirido o direito de votar em seus candidatos, uma das normas estabelecidas pelo novo código eleitoral foi a obrigatoriedade de os eleitores serem alfabetizados. O Brasil, nessa época, possuía um alto indice de analfabetos, que estariam automaticamente proibidos de participar do pleito presidencial.

Voltando nosso olhar para o caso do município aqui estudado, observa-se que essa exigência impossibilitava que um número considerável de moradores participasse das escolhas de seus representantes politicos, pois o censo do IBGE de 1940 apontava que apenas $17 \%$ desses sabiam ler e escrever. ${ }^{10}$ Mas, desse percentual de letrados que correspondia a 15.503 habitantes de Garanhuns, apenas 5.193 alistaram-se para votar na eleição presidencial, como foi noticiado no jornal Diário de Garanhuns. ${ }^{11}$

Enquanto o ex-governador de São Paulo, Armando de Sales Oliveira, tentava conquistar o apoio do presidente Vargas e das lideranças dos outros estados brasileiros, sem sucesso; coube então ao paraibano José Américo de Almeida a simpatia dos políticos da situação, que o apresentava como o candidato

\footnotetext{
${ }^{10}$ INSTITUTO BRASILEIRO DE GEOGRAFIA E ESTATÍSTICA. Censo Demográfico: População e Habitação - quadros de totais referentes ao estado e de distribuídas segundo os municípios. Série Regional Parte IX - Pernambuco - Tomo 1. 1940. Disponível em: <http:/ / biblioteca.ibge.gov.br/visualizacao/monografias/GEBIS\%20-\%20RJ/CD1940/Censo\%20 Demografico\%201940_pt_IX_t1_PE.pdf>_Acesso em: 06 set. 2010.

${ }^{11}$ O Eleitorado deste Município. Diário de Garanhuns, Garanhuns. 10 de novembro de 1937, p. 3 - APEJE
} 
do presidente. Plínio Salgado, liderando os integralistas, procurava apresentar-se como uma alternativa nacionalista, frente a um cenário discursado por ele e outros da época como marcado pela ameaça comunista e decadência do liberalismo. No decorrer da disputa eleitoral, os votos dos camisas-verdes pareciam não ser suficientes para eleger seu líder, comparados com a aceitação dos outros candidatos. Mas, como meta, teremos as análises sobre as produções discursivas dos que apoiavam Salgado e não de suas chances reais e/ou fictícias de ter chegado à presidência do país.

Os estudos sobre as eleições, como bem dissertou René Rémond, possibilitam importantes discussões relativas às estratégias de formação da opinião pública em torno de um candidato, ou das ideias que ele representa. Nesse caso, a repercussão em volta dos que disputam o poder por meio do voto depende da aceitação e identificação popular com o nome e propostas do elegivel. Além da maneira como a campanha foi gerenciada pelos membros do partido e, ao mesmo tempo, pelo descrédito que conseguiu associar aos seus opositores. Desse modo, de acordo com Rémond:

A campanha é parte integrante de uma eleição, é seu primeiro ato. Não é apenas a manifestação das preocupações dos eleitores ou a explicação dos programas dos candidatos e dos temas dos partidos, é a entrada em operação de estratégias, a interação entre os cálculos dos políticos e os movimentos de opinião. ${ }^{12}$

Esse autor destacou, em seu texto, a importância das eleições para a Nova História Política, pois a partir desses eventos democráticos, os pesquisadores poderiam travar discussões relativas à opinião pública e à formação e/ou substituição de grupos que assumem o poder, ampliando assim o leque de abordagens sobre assuntos políticos, saindo das análises tradicionais pautadas no levantamento de datas, nomes e fatos. No entanto, como a eleição abordada nesse trabalho não chegou a se concretizar, pois Getúlio Vargas ministrou um novo golpe político e implantou o Estado Novo (1937-1945), nossa escrita se voltará para as estratégias utilizadas nas propagandas desenvolvidas pelos garanhuenses, principalmente os militantes integralistas,

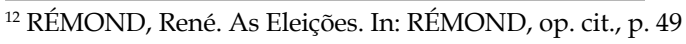


em torno do nome dos candidatos à presidência. Desse modo, dedicaremos nossas análises para o "primeiro ato" das eleições, como indicou Rémond. ${ }^{13}$

O apelo por parte dos propagandistas integralistas ao ressentimento contra os membros comunistas que tinham tentado um golpe de Estado em 1935 (fato que ficou conhecido como Intentona Comunista) conquistou a simpatia de outros grupos sociais que não eram necessariamente filiados à AIB. Em Garanhuns, o corpo editorial do jornal $O$ Monitor, pertencente à Diocese do município, começou a noticiar o desenrolar das disputas entre os candidatos, dando certo destaque à obra política de Plínio Salgado contra o comunismo no Brasil. No início do século XX, como analisou Rodrigo Patto Sá Motta, a Igreja Católica foi uma das instituições que percebia no comunismo uma ameaça aos preceitos cristãos, associando o pensamento político da esquerda ao demônio e a negação aos ensinamentos do próprio Jesus Cristo. ${ }^{14}$

Os jornalistas desse periódico da Diocese de Garanhuns, muitos deles padres, mesmo não sendo oficialmente aliados dos integralistas, sabiam que vários dos seus leitores e fiéis da Igreja simpatizavam com o nome de Salgado, que, defendendo o lema: Deus, Pátria e Família, tornava-se o candidato que mais se aproximava dos eleitores católicos. Desse modo, cientes da predileção de alguns de seus consumidores/leitores, os membros do referido órgão de imprensa começaram a divulgar enunciados comuns com frequência tanto às formações discursivas dos membros da Igreja Católica como da AIB, principalmente no que concernia ao anticomunismo.

Mesmo mantendo uma produção discursiva alinhada com o que era pregado pelos camisas-verdes, apenas no segundo semestre de 1937 foi que o corpo editorial de O Monitor começou a abordar com maior frequência as disputas eleitorais e apresentar um posicionamento mais definido sobre o candidato que apoiaria. Como aparece no artigo:

Duas cousas... três cousas...

\footnotetext{
${ }^{13}$ Ibidem.

${ }^{14}$ MOTTA, Rodrigo Patto Sá. Em guarda contra o “Perigo Vermelho": o anticomunismo no Brasil (1917-1964). São Paulo: Perspectiva: FAPESP, 2002, p. 18-29. 
Uma campanha política para uma eleição que não aconteceu: as práticas ...

O paiz soffre a muito justa agitação politica preparatória das eleições presidenciaes de janeiro proximo. Três candidatos, os partidos e os governos, delimitam os campos e accendem o facho da luta e da campanha, tudo muito bem: democracia, reivindicações, frentes populares, uniões democráticas, partidos, scisões nos partidos...

Há, porém, de inicio, três cousas que devem ser consideradas pelos brasileiros de todos os partidos.

Primeira: O Sr. Mangabeira, proclama-se homem das esquerdas e diz que o Sr. José Américo é pelo espirito e pelo coração da esquerda, o que é falso, mas não deixa de patentear, aos mais ingênuos, que este esquerdista ou communista Mangabeira, assume papel saliente na campanha e terá mais tarde, optima situação para ajudar a próxima investigação vermelha.

Segundo: O Sr. Plinio Salgado lançou ao Brasil o grito de alarma, demonstrando com uma superioridade que edifica e uma documentação que assombra, a obra satânica dos vermelhos, seu fortalecimento e sua táctica e campanha ativamente realizadas e em marca de cabal realização.

Terceira: Os vermelhos provocam uma chacina Barbara, em Campos, e em jornaes a serviço de propaganda de uma candidatura, torcem os factos e buscam a responsabilidade de uma organização que tem seu candidato à presidência da Republica, sem tocar, na façanha communista.

São três cousas que dão muito lógica e seguramente, a seguinte conclusão! O comunismo está de vento em popa no Brasil e a questão presidencial com a terrivel fome de solidariedade e de votos, está cegando candidatos e enfraquecendo governos, executando o plano soviético. ${ }^{15}$

O Chefe Nacional da AIB aparece como aquele que denunciou em sua campanha a ameaça comunista que, supostamente, espreitava a sociedade brasileira para atacá-la. No entanto, a situação da AIB era ambigua, pois simultaneamente à tentativa de se enquadrar em um cenário político democrático, os seguidores de Salgado continuavam se colocando como inimigos desse sistema. Ressaltamos que o integralismo precisou se adaptar às exigências da Constituição vigente no pós-1934, passando por um processo de reformulação institucional. A questão era que o integralismo tinha sido criado enquanto um movimento cívico de estudos dos problemas nacionais, não se enquadrando

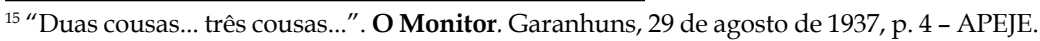


na categoria de partido político legalizado dentro do sistema democrático. Para se adequar e poder concorrer às eleições em 07 de março de 1935, depois do II Congresso Integralista em Petrópolis, a AIB deixava de ser um movimento cultural para se tornar um partido político, adequando-se ao sistema democrático.

Nessa primeira fase, o discurso doutrinário de Salgado voltava-se para incutir entre seus militantes o desejo de participarem de uma revolução espiritual e cultural, tendo como norte as propostas presentes no Manifesto de Outubro, que se dava em torno da criação de um Estado forte, pautado em preceitos nacionalistas e cristãos. Enquanto no segundo momento, quando passou para partido político depois do citado Congresso, os intelectuais ligados à AIB começaram a divulgar falas que apontavam outros caminhos para se chegar ao poder: "o percurso não seria mais uma 'revolução espiritual', mas a partir do voto popular."16

Em 1937, em resposta às acusações de serem antidemocráticos, os camisas-verdes lançaram um plebiscito para a escolha do seu candidato, dando, assim, a oportunidade aos militantes de decidirem quem concorreria pela AIB. Dessa forma, os membros do Sigma $\left(\sum\right)$ de todo o país, em idade de votar, deveriam participar da escolha do nome do seu representante à presidência. Os núcleos então começaram a se organizar para o processo de seleção, convocando todos os inscritos a votarem, como aconteceu em Garanhuns.

\section{GABINETE DA CHEFIA MUNICIPAL}

O Chefe Municipal de Garanhuns no uso das suas atribuições e em obediência às determinações da Chefia Nacional, resolve:

a) Ficam convocados todos os Integralistas deste Município para a sessão de 23 do corrente, na qual terá lugar o plebiscito para a escolha do candidato da AIB à Presidência da Republica;

b) Sendo obrigatório o comparecimento de todos os Integralistas à referida sessão, comunica esta Chefia que serão

\footnotetext{
${ }^{16}$ Dentre as obras que podem explicitar o processo de transformação institucional do integralismo, destacamos: CAVALARI, Rosa Maria Feiteiro. Integralismo. Ideologia e organização de um partido de massa no Brasil (1932-1937). Bauru: Editora do Sagrado Coração, 1999.
} 
punidos com suspensão todos aqueles que faltarem sem causa justificada. ${ }^{17}$

Desse modo, os integralistas, antes acusados de antidemocratas, começaram a questionar a postura dos outros partidos que se diziam democratas, mas não davam o direito aos seus partidários de escolherem os seus elegiveis. Ao mesmo tempo em que tentavam passar uma imagem de democratas, as práticas autoritárias permaneciam nos discursos integralistas. Isso pode ser percebido na convocação feita aos militantes de Garanhuns para escolher o candidato à presidência da AIB, pois os membros que não obedecessem às determinações de seus superiores seriam "punidos com suspensão".

Ao analisarmos essa prática normatizadora do chefe municipal da AIB, lembramo-nos da observação de Michel Foucault em Vigiar e Punir, quando escreveu: "O castigo disciplinar tem a função de reduzir os desvios. Deve, portanto, ser essencialmente corretivo." ${ }^{18}$ A correção punitiva, defendida por esse autor, pode ser percebida na convocação feita aos camisas-verdes de Garanhuns no jornal $A$ Razão, pois ao não comparecer à escolha do candidato à presidência pela AIB, o militante estaria cometendo uma grave falta aos propósitos ideológicos e juramentos ao qual estava preso por uma questão de disciplina imposta pelo partido. Desse modo, estabelecer uma punição aos que ferissem suas obrigações possuía a função de "obrigar" que todos cumprissem com o seu dever, além de desestimular as irregularidades entre os militantes.

Como resultado do plebiscito da AIB, Plínio Salgado saiu como vencedor com uma votação esmagadora e sem causar nenhuma surpresa entre os militantes e os outros brasileiros que acompanharam esse processo. Com a escolha de Salgado, a organização da campanha integralista ficou sob o comando da Secretaria Nacional de Propaganda (SNP) que atuou a partir de uma articulação com a Secretaria Nacional das Corporações $e$ Serviços Eleitorais (SNCSE), responsável direta pela coordenação com os militantes de base, ou com os simpatizantes. Essas duas secretarias nacionais e as suas versões estaduais, municipais

${ }^{17}$ Gabinete da Chefia Municipal. A Razão. Garanhuns, 09 de maio de 1937, p. 4 - APEJE.

${ }^{18}$ FOUCAULT, Michel. Vigiar e Punir: nascimento das prisões. 31 ed. Petrópolis: Vozes, 2006, p. 150. 
e distritais seriam encarregadas pela divulgação e defesa do candidato da AIB, além de terem de conquistar novos eleitores para este. A organização hierarquizada das secretarias dava à AIB condições de divulgar as propostas e pensamento de Salgado em todo o país, esperando com isso uma unidade doutrinária dos camisas-verdes no Brasil.

O bacharel em Direito e vereador integralista de Garanhuns, Antônio Tenório de Almeida, assumiu também a função de Secretário Municipal de Corporações e Serviços Eleitorais (SMCSE), o qual recebia ordens diretas da SNCSE. Dessa forma, o partido procurava construir uma homogeneidade na campanha presidencial em todo o país, estabelecendo o quê e como os discursos deveriam ser noticiados nos periódicos e pelos membros dos núcleos da AIB. Uma das circulares enviadas a esse camisa-verde garanhuense foi apreendida por investigadores da Delegacia de Ordem Politica e Social de Pernambuco (DOPS-PE) e arquivada em um dos prontuários funcionais. Esse documento vindo da SNCSE mandava o referido militante divulgar na cidade uma palestra dada por Plínio Salgado aos microfones da Rádio Mayrink Veiga, no Rio de Janeiro, em 02 de agosto de 1937.

CIRCULAR N ${ }^{\circ} 2$

DO DIRECTOR NACIONAL DOS SERVIÇOS ELEITORAES E POLITICOS AOS COMPANHEIROS Antônio Tenório de Almeida.

Estando os bolchevistas em franca e activa preparação do golpe com que pretendem investir contra as instituições, e escravisar a Pátria, conforme o aviso dado à Nação pelo CHEFE NACIONAL em 2 do corrente pelo Radio Mayrink Veiga e conforme vem demonstrado os últimos factos do conhecimento público, mais do que nunca se torna necessário conclamar todos os brasileiros dignos para o combate a Moscou.

Por isso, afim de alertar a Nação Brasileira, julgamos ser da maior necessidade que o referido discurso do CHEFE NACIONAL seja lido, se já o não foi, na Câmara de que o Companheiro faz parte e requerida a sua inserção nos annaes. [...]

Certos estamos de que o Companheiro comprehenderá os relevantes serviços que poderá prestar dessa forma ao Brasil, neste momento angustioso de sua vida.

Pelo Bem do Brasil, Anauê! ${ }^{19}$

${ }^{19}$ Circular $\mathrm{n}^{\mathrm{o}}$ 2. De Diretor Nacional dos Serviços Eleitorais e Políticos aos companheiros. Prontuário Funcional $n^{\circ} 4938$. DOPS-PE/APEJE (Grifo nosso). 
Provavelmente, outros núcleos receberam o mesmo informe e utilizaram dos meios que possuíam para divulgar o discurso do candidato da AIB. O apelo ao sentimento patriótico marcava a correspondência dos militantes que acreditavam estar envolvidos em uma batalha em defesa do Brasil e da religião cristã, contra as forças comunistas. Destacamos que Antônio Tenório, além de ocupar o cargo de SMCSE, era também vereador em Garanhuns e durante muito tempo foi professor de Português no Colégio Diocesano, sendo conhecido como uma liderança local entre os leigos católicos e bem relacionado com os membros do clero local.

Na referida entrevista, Salgado dedicou-se não a expor o plano político da AIB, nem como seria o Brasil caso ele fosse eleito. Mas voltou-se a desferir ataques contra o comunismo e tentar relacionar a imagem dos seus opositores a essa corrente ideológica e política, associando os adversários aos interesses da Rússia Soviética e à ideia de um materialismo sem Deus. A mesma circular enviada ao bacharel Antonio Tenório de Almeida indicava a leitura dos jornais A Offensiva e o Correio da Manhã, nos quais estava escrita na íntegra a palestra do Chefe Nacional da AIB.

O jornal A Offensiva, sob a orientação do próprio Plínio Salgado, dedicou a primeira e quarta página à transcrição da fala do candidato integralista que, em certo momento, teria discursado:

Os camisas-verdes não podiam tomar posição em uma das duas correntes que apóiam os candidatos majoritário e minoritário, porque tinha conhecimento de directivas da Internacional Communista, a qual determinou que o bolchevistas e as suas chamadas forças de vanguarda se dividissem, infiltrando-se nos dois campos, afim de gozarem as franquias inherentes ao exercício de direitos eleitoraes e a protecção de personalidades influentes nos governos estaduaes e federal.

Tinhamos, pois, para estar vigilantes em vosso beneficio, brasileiros de todas as correntes e de todas as classes, de nos conservarmos sozinhos. O contrario seria desarticular todo um serviço pacientemente organizado por nós, de vigilância contra o communismo, e seria enfraquecer a cohesão das forças civis e militares mais activas e informadas do paíz, promptas para oppôr tenaz resistência contra a insurreição vermelha ou o golpe 
technico. Isolados, estamos organizados: mantemos o mesmo estado de animo, de insomne vigilância, de combatividade e, notadamente, de informação constante sobre os passos dos bolchevistas. Estaes vendo, pois, meus patrícios, que não é a ambição, nem a vaidade, nem a egolatria, nem o interesse regional, nem a politica de grupos que me levam a comparecer às urnas; o que eu objetivo é, em torno da candidatura Integralista, arregimentar forças invulneráveis ao virus soviético e que talvez mais cedo do que pensaes, terão de salvar as instituições, oppondo uma barreira [...] à investida de Moscou. ${ }^{20}$

Na leitura desse trecho da fala de Salgado, observa-se que retomando um tema presente não só na campanha presidencial, mas no próprio percurso político e intelectual da AIB, o pedido feito ao integralista de Garanhuns que divulgasse essa palestra em seu município apontava para a tentativa de instigar o ressentimento em relação aos grupos de esquerda. Novamente recorrendo à fórmula dicotômica que dividia o cenário entre o bem e o mal, o lider integralista, a exemplo do que seus seguidores também procuravam fazer, argumentava que a ameaça "vermelha" (comunista) não era apenas fruto de brasileiros insatisfeitos com o governo. Na realidade, esses seriam manipulados por planos de dominação que vinham de outro país, a Rússia.

A propaganda integralista na referida cidade teve no anticomunismo sua principal bandeira, com a qual esperavam conquistar os votos dos garanhuenses. Essa prática tornou-se comum no jornal $A$ Razão, que procurava articular notícias do cenário político internacional e nacional com o que acontecia na região. Ao analisar a produção de outros pesquisadores, o combate ao comunismo servia então como um dos elementos para homogeneizar os discursos propagandísticos dos camisasverdes pelo país. Assim, buscaremos ver a partir de agora como as propostas e disputas apresentadas como de âmbito nacional pelo integralismo foram acompanhadas e debatidas pelo periódico da AIB local.

${ }^{20} \mathrm{O}$ communismo contra o Brasil. A Offensiva. Rio de Janeiro, 04 de agosto de 1937, p. 1. 
Uma campanha política para uma eleição que não aconteceu: as práticas ...

\section{A propaganda integralista em Garanhuns: Os discursos de Salgado no jornal $A$ Razão}

Antes mesmo de ser escolhido pelo plebiscito como o candidato integralista em 1937, Plínio Salgado já tinha lançado, um ano antes, em um conclave para as altas patentes do AIB, o projeto de governo intitulado de Manifesto-Programa. Esse programa eleitoral foi apresentado por ele enquanto um amadurecimento e aprofundamento das propostas feitas anteriormente no Manifesto de Outubro de 1932.

A divulgação das propostas desse Manifesto-Programa foi feita de maneira incessante pelos meios de comunicação ligados à AIB, como ressaltou Rodrigo dos Santos de Oliveira em sua tese, que, ao tratar dos periódicos desse movimento, destacou a importante função dos órgãos de imprensa nesse processo de convencimento da opinião pública em torno da candidatura de Salgado. Esse autor, ao analisar o lugar estratégico da imprensa na campanha integralista, ressaltou que ela teria a função de "doutrinar, dominar pelo consenso, eliminar vozes dissidentes e garantir uma linearidade ideológica" ${ }^{21}$ Ao direcionarmos nossa atenção para o município de Garanhuns, além dos exemplares desse programa eleitoral terem provavelmente circulado por lá, ao menos nas mãos daqueles que frequentavam o núcleo, o jornal A Razão também começou a colocar trechos do referido texto nas edições de 1937, para que seus leitores, aos poucos, entrassem em contato com as propostas dos partidários do Sigma $(\Sigma)$ para o Brasil pós-eleição. ${ }^{22}$

Mas, não só os panfletos e jornais eram utilizados, o desenvolvimento das tecnologias, no início do século XX, interferiu

${ }^{21}$ Cf.: OLIVEIRA, Rodrigo Santos de. Imprensa Integralista, Imprensa Militante (19321937). Tese (Doutorado em História). PUC-RS, 2009, p. 274.

${ }^{22}$ A suposição de que os militantes integralistas de Garanhuns entraram em contato com o Manifesto-programa alicerça-se no fato que no decorrer do Estado Novo, em uma das diligências da polícia política de Vargas, além dos livros já citados nesse trabalho, os agentes da lei apreenderam também o seguinte: "Grande numero de exenplares de jornaes Integralistas, Boletins, Hymnos, Manifestos e Prospectos de propaganda etc...". Logo, dentre o material recolhida pela DOPS-PE, havia também o referido documento para as eleições de 1938, que não chegaram a se realizar. Cf.: Relação de livros, objetos, documentos, photografhias e materiaes de expediente e propaganda, apprehendidos em domicílios de integralistas desta cidade. Prontuário Funcional $\mathbf{n}^{\mathbf{0}}$ 1026. DOPS-PE/APEJE. 
diretamente nesse processo propagandístico, possibilitando uma abrangência do raio de atuação dos envolvidos. Esse foi o caso do rádio que foi usado para alcançar aqueles prováveis eleitores que não tinham o costume de ler jornais, ou não se envolveram ativamente em algum partido ou agremiação de cunho político. Nas primeiras décadas do século passado, o rádio foi o meio de comunicação que juntou muitos ouvintes em todo o país que atentamente escutavam seus programas e os pronunciamentos de intelectuais e políticos. Sobre a relevância do rádio nas campanhas eleitorais realizadas no decorrer de 1936 e 1937, destacamos o trecho de um artigo do A Razão:

Estamos na fase aguda da sucessão presidencial. A imprensa, o rádio e o cinema vêm sendo usados no endeusamento dos candidatos liberaes e na propagação das suas promessas ao bom povo brasileiro.

Mas o radio é o veiculo por excelência: Oradores e mais oradores ocupam todos os dias os microfones das estações do paíz. ${ }^{23}$

Os rádios/as vitrolas eram então mais uma atração nas casas e nos espaços de relações sociais, como os cafés, onde os clientes e transeuntes reuniam-se para ouvir musicais, informativos e os programas de locutores, que muitas vezes recebiam além de personalidades artísticas, importantes políticos. Como fizeram os outros candidatos em suas campanhas, Plínio Salgado também se utilizou desse meio de comunicação para levar seus discursos além dos que frequentavam os núcleos da AIB, ou liam as obras e periódicos dos integralistas. Em dois momentos diferentes, no início de novembro de 1937, em que os militantes de Garanhuns ouviam a voz de seu Chefe Nacional em um rádio colocado no núcleo local, faltou energia elétrica na cidade. Mesmo com esse incidente, ou suposto boicote comunista segundo os jornalistas da AIB local, a presença dessas notícias no periódico do núcleo indica uma prática dos integralistas de se reunirem para ouvirem no rádio as determinações vindas da liderança a nível nacional.

No jornal A Razão, no decorrer de 1937, quando as disputas eleitorais se acirraram, foi criada uma coluna intitulada: A propósito, assinada por Matoso, provavelmente o pseudônimo

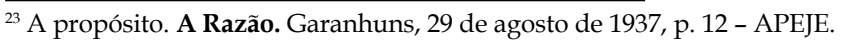


do então Chefe Municipal da AIB, o dentista Mario Matos. Esse integralista procurou articular sua concepção sobre as questões do cotidiano político do município com o que acontecia no resto do país. Os seus textos eram norteados por uma prática anticomunista, característica comum a outros jornalistas do movimento, que em muitos momentos associava a imagem dos comunistas aos judeus e, principalmente no caso dos garanhuenses, aos maçons.

Os textos de Matoso procuraram ambientar os debates e choques entre os integralistas e opositores nas feiras e em pontos de encontros populares. Em um desses artigos, o Café Central - localizado na Av. Sto. Antônio, centro comercial de Garanhuns - foi o cenário onde, em torno de uma camisa de cor verde, simbolizando a farda dos militantes da AIB, um oposicionista atacou Salgado e seus seguidores. Nessa ocasião, segundo o seu artigo, os clientes foram testemunhas de uma das "mais odientas manifestações de uma cólera incontida". ${ }^{24}$ "A tal camisa, simplesmente por ser de cor verde, fora rasgada, estraçalhada, babada de ódio e expostos os seus pedaços à risadaria dos apaniguados defensores das 'liberdades democráticas". ${ }^{25} \mathrm{~A}$ descrição da sequência de atos desrespeitosos em relação a um símbolo da AIB (a camisa-verde) demonstrava a fúria e barbárie dos adversários locais contra o integralismo.

Em outro momento, apropriando-se da figura de populares, como a representação do matuto indignado com os que falavam mal da AIB, Matoso apontava para uma suposta aceitação que os camisas-verdes tinham entre os mais simples brasileiros, procurando assim vencer as barreiras que colocavam o integralismo como um grupo de jovens intelectuais de classe média.

O Integralismo conquista, empolga as elites e fascina todos os governantes de boa vontade e que de fato desejam ver o Brasil unido, forte e respeitado.

O integralismo conquista o povo brasileiro.

$\mathrm{Eu}$, outro dia, ouvi um matuto dizer em certa roda de inimigos do Sigma e que certamente "tosavam":

\footnotetext{
${ }^{24}$ Registrando. A Razão. Garanhuns, 25 de julho de 1937, p. 4 - APEJE.

${ }^{25}$ Idem.
} 
"Seu moço, eu não adoto, mas à morá é boa" - Era um pequeno agricultor de Garanhuns quem assim dizia. Eu ouvi. ${ }^{26}$

O jornal A Razão assumia em Garanhuns a função de divulgar e popularizar a imagem de Salgado, que aparecia nas páginas desse periódico como o legítimo representante dos preceitos patrióticos, sendo esse seu lugar reconhecido tanto entre os intelectuais como por populares, como pelo matuto citado anteriormente por Matoso. Enquanto isso, os seus adversários eram descritos pelos discursos integralistas, não apenas como oponentes políticos, mas como inimigos da pátria e muitas vezes da própria fé cristã, como acontecia com os considerados comunistas.

Com intenção de construir discursivamente uma paisagem politica a partir de uma premente ameaça das forças estrangeiras, os intelectuais integralistas apresentavam-se como única força nacionalista capaz de governar o país, alicerçando-se em bases da tradição cristã. Almejando uma suposta vitória pelas urnas, a liderança da AIB desejava dar início à implantação do Estado Integral entendido como um estado forte e com base na administração corporativa. Como observou Giselda Brito Silva: "Essa proposta trazia como ideia central um projeto de 'Organização Corporativa do Estado forte' que não escondia a intenção intervencionista sob o discurso de defesa dos princípios morais e tradicionais[...]"27

No artigo "Candidato...", publicado no A Razão, as imagens dos candidatos Armando Sales Oliveira, José Américo de Almeida e do próprio Plínio Salgado foram descritas a partir de estereótipos comuns ao repertório integralista de discursos. Como pode ser visto logo a seguir:

CANDIDATOS...

O povo brasileiro já conhece os candidatos à presidência da Republica nas próximas eleições.

Um é indicado pelas chamadas "forças majoritárias" do paiz; outro, pelas chamadas "forças de oposição" ao Catete e um terceiro é o indicado pelo único Partido Político de âmbito nacional.

\footnotetext{
${ }^{26}$ A propósito. A Razão. Garanhuns, 25 de abril de 1937, p. 4 - APEJE.

${ }^{27}$ SILVA, Giselda Brito. A Lógica da suspeição contra a força do Sigma: discursos e polícia na repressão aos integralistas em Pernambuco. Tese (Doutorado em História) UFPE/CFCH, 2002, p. 48.
} 
Do primeiro se aguarda a palavra sobre o seu programa; do segundo, já se conhecem alguns discursos; e do terceiro, há quase dois anos, já se sabe qual será a sua diretriz, já se conhecem as linhas mestras do seu programa, já se sabe enfim como vae governar, o que quer fazer e como fará aquilo que quer.

O primeiro, como candidato das "forças majoritárias", terá de fazer o seu programa de acordo com elas. E são da liberal-democracia... E elas são de homens cheios de erros que a "outubrada" procurou combater, mas que, no dizer do senador Costa Rego, os aumentou cada vez mais...

O segundo é um candidato dos "sindicatos extrangeiros", é um candidato judeu e casado, ao que se diz, com uma judia...

É também um candidato simpático à Maçonaria...

É um candidato que a sua propaganda com rios de dinheiro... É um candidato do celebérrimo Assis Chataubriand e da sua insidiosa, venenosa "cadeia" de jornaes...

O terceiro vem de um grande movimento de uma nova doutrina, é um candidato, do Brasil e do seu povo. ${ }^{28}$

A descrição feita do primeiro candidato era voltada para Armando Sales de Oliveira, preferido das elites econômicas do sudeste do país. O segundo era o paraibano José Américo de Almeida, acusado de ser conivente com os grupos da esquerda e financiado pela maçonaria. Mas, aparecia em sua propaganda como o preferido de Vargas. Enquanto o terceiro candidato seria Plínio Salgado. O fato é que, para os integralistas, nenhum dos dois primeiros candidatos dos partidos liberais tinha condições de administrar o país e, principalmente, protegê-lo das empreitadas dos inimigos políticos da nação. Ao passo que o terceiro candidato, Salgado, pertencia a "[...] um grande movimento de uma nova doutrina, é um candidato do Brasil e do seu povo."29

Concomitantemente aos camisas-verdes garanhuenses que trabalhavam em torno do nome de Salgado apresentando-o como um intelectual cristão apto para resolver os problemas sociais, os que defenderam os candidatos de tendências liberais (tanto Armando Sales de Oliveira como José Américo de Almeida) atacavam o integralismo e seu líder, mostrando-os como uma negação aos preceitos de liberdades que sustentavam a República Democrática do Brasil. Uma das características

28 “Candidatos...". A Razão. Garanhuns, 30 de maio de 1937, p. 1 - APEJE.

${ }^{29}$ Ibidem. 
que observamos na análise da propaganda eleitoral para as eleições que deveriam ocorrer em 1938 foi que tão importante quanto a defesa das propostas de um determinado candidato, estava também o ataque à honra dos adversários. Deslegitimar politicamente o oponente surtia o efeito de legitimar aquele que o combatia.

Esse cenário de disputa política na cidade pode ser percebido em uma carta do Chefe Municipal, Mario Matos, para o líder da AIB em Rio Branco (atual Arcoverde), Antônio Napoleão.

Garanhuns, 30 de julho de 1937

Caro companheiro Antonio Napoleão

Anauê

Como vamos por ahi?

Aqui a cousa vae bôa. Os jornaes da terra, que são em número de três liberaes, assestaram as baterias contra nós e ha quasi um meio tem sido forte o troteio. Atiram, porem, com canhões de pouco alcance e com maus atiradores. As balas geralmente, fazendo voar pelos ares as suas próprias fortificações. A nossa "a razão" continua na vanguarda. É nosso propósito tornal-a diária, ou pelo menos circulando a escrita nesse sentido, o que muito nos tem custado e muita raiva irá fazer aos nossos adversários se conseguirmos pol-a em dia. $[. . .]^{30}$

Apreendida pelos investigadores da DOPS-PE, provavelmente durante as incursões nos núcleos da AIB-PE durante o Estado Novo, a referida carta apresenta um cenário de disputas, no qual os inimigos liberais atacavam os integralistas que pretendiam responder intensificando a propaganda a favor de Salgado, no decorrer de $1937 .{ }^{31}$ O clima de animosidade apresentado por essa correspondência refletia o momento de disputas politicas vivenciado pelos garanhuenses que se utilizavam dos jornais para fazerem campanhas em prol de seus candidatos e para atacar os adversários.

${ }^{30}$ Carta do Chefe Municipal de Garanhuns, Mario Matos, para Antônio Napoleão, Chefe Municipal de Rio Branco. Prontuário funcional $\boldsymbol{n}^{\mathbf{0}} \mathbf{4 6 2 6}$. DOPS-PE/APEJE. (Grifo nosso).

${ }^{31}$ A historiadora Marcilia Gama destacou que a construção de um acervo documental, formado por relatórios policiais e material apreendido pelos agentes da DOPS-PE, possibilitou a elaboração de uma teia de informação. Essas informações davam uma maior eficiência no trabalho policial, que poderia localizar nos prontuários os nomes e crimes dos considerados subversivos. Cf.: SILVA, Marcília Gama da. O DOPS e o Estado Novo: os bastidores da repressão em Pernambuco (1935-1945). Recife, UFPE. 187 f. Dissertação (Mestrado em História) UFPE/CFCH, 1996. 
Dentre os periódicos que circulavam nas mãos dos leitores de Garanhuns e que optaram em fazer oposição à candidatura de Salgado à presidência, selecionamos o jornal O Mensageiro, pertencente à loja maçônica O Mensageiro do Bem. Com uma circulação quinzenal, desempenhou, concomitantemente à propaganda a favor do candidato José Américo de Almeida, um combate ao integralismo, que se fez presente em todas as edições desse jornal mantido pela maçonaria garanhuense.

\section{O Mensageiro: o combate dos maçons aos integralistas de Garanhuns em 1937}

No segundo semestre de 1937, os comunistas começaram a ser descritos, no jornal A Razão, como dependentes financeiramente da maçonaria. Essa percepção se deu, provavelmente, por causa da intensificação das atividades políticas dos membros da loja maçônica da cidade, O Mensageiro do Bem, na campanha favorável a José Américo de Almeida e no combate às atividades do núcleo integralista local.

Ao colocar novos elementos na constituição da imagem discursava do seu adversário, os jornalistas/integralistas de Garanhuns utilizaram-se do cotidiano de disputas locais, como reflexo da situação da política a nível nacional. Esses camisasverdes começaram a noticiar boatos de que os comunistas estavam sendo financiados pelos maçons, mas sua intenção era a de atacar os opositores da cidade, dentre os quais muitos eram membros da loja maçônica. Em 29 de setembro de 1937, na edição comemorativa de dois anos do jornal A Razão, o artigo de Hidalgo Cesar, "Planos Sinistros...", traçou o campo de batalha que os integralistas, na defesa da fé e dos bons costumes, teriam que enfrentar para combater as forças conjuntas dos maçons e comunistas.

De braços-dados, Maçonaria e Comunismo, com seus martelos destruidores de nacionalidades e igrejas, procuraram destruir estas pedras solidas em que Plínio Salgado assentou os fundamentos de uma pátria nova que jamais se venderá a Moscou e se vilipendiará nos antros tétricos e sinistros da Maçonaria. O Integralismo está ai[...] ele não teme o punhal, a mazorca, a calunia a traição, porque com ele, com o seu chefe, na defesa da nossa 
Pátria e no bem estar da família, está com sua dextra de proteção Aquele a Quem os Judeus Maçãos renegam, os Comunistas ridicularizam, Supremo Arbitro das Pátria: DEUS. ${ }^{32}$

Nesse artigo, o integralismo enfrentaria sem medo, para defender o Brasil, um inimigo que passava na argumentação de Hidalgo Cesar pelas imagens dos maçons, judeus e comunistas. Nos textos dos militantes da AIB de Garanhuns, percebe-se essa lógica discursiva em que os elementos que formavam o lema: Deus, pátria e família, apareciam como ameaçados por forças estranhas aos brasileiros cristãos. No caso, Moscou surgia não como um espaço geográfico, mas como exemplo da materialização da opressão comunista sobre um povo que supostamente teria virado as costas para Deus. Sobre a construção de sentidos a partir da utilização e repetição de certas imagens, Antoine Prost destacou: "A frequência dos termos, das expressões, das opiniões ou dos julgamentos parece ser um indicador seguro de sua importância objetiva. [...] poderiamos sustentar que há termos tão carregados de sentido que bastaria empregá-los uma vez para colorir todo um texto[...]"33 E a Rússia e/ou Moscou foram utilizadas nos discursos integralistas com essa função de "colorir", trazendo junto aos nomes desses lugares um conjunto de estigmas negativos associados a eles pelos seus opositores.

Em respostas às acusações dos seguidores de Salgado, os maçons da cidade criaram o jornal O Mensageiro. Esse periódico circulou entre os meses de maio e outubro de 1937, com apenas 12 edições publicadas. No decorrer da leitura dos artigos desse periódico, encontram-se alguns pontos que se repetiam na argumentação dos que contribuíam com ele. Dentre as principais características, podemos destacar: a) a tentativa de criação de uma imagem positiva ao grupo de maçons, procurando desconstruir o perfil apresentado pelos integralistas em sua propaganda; b) a associação do integralismo às forças estrangeiras, principalmente a Alemanha Nazista e a Itália Fascista, buscando, assim, minar o caráter nacionalista pregado pelos seguidores de Salgado; c) a apresentação de uma alternativa política, com bases no liberalismo, ao projeto de Estado Integral da AIB.

32 "Planos Sinistros...". A Razão, Garanhuns, 29 de setembro de 1937, p. 6 - APEJE.

${ }^{33}$ PROST, Antoine. As Palavras. In: RÉMOND, R. op. cit., p. 299. 
Uma campanha política para uma eleição que não aconteceu: as práticas ...

O Vigilante, pseudônimo de um dos jornalistas de O Mensageiro, procurava responder as acusações dos integralistas locais que atacavam a maçonaria. Em um de seus textos, esse autor argumentou:

Na França, Suíssa, Holanda, Inglaterra, Estados Unidos e outros paizes onde o progresso se requintou, a maçonaria é respeitada e os maçons, com justiça, são tidos como cidadãos uteis à pátria e necessários à ordem pública. Um fato, porém, nos chama a atenção, nos conturbados dias em que vivemos, Queremos nos referir ao fechamento das lojas maçônicas na Rússia, Itália, Alemanha e Portugal. Quer dizer, nos paízes onde predominam governos ditatoriaes. Reparou o leitor como "todo o caminho dá na venda?” As ditaduras são sempre iguais. Sejam brancas, azuaes, verdes, pretas ou vermelhas. Ninguém, sem um exame químico completo, distingue o cogumelo venenoso do não venenoso. Ambos nascem nas esterqueiras. Não há, na essência, nos processos e nos fins, nenhuma diferença entre Berlim e Moscou. [... $]^{34}$

Nessa mesma edição, o corpo editorial publicou também o seguinte:

\section{O FACISMO, O NAZISMO E O INTEGRALISMO}

$\mathrm{Na}$ emergência de desequilíbrio que atravessamos, quando os laços moraes da sociedade se desentrelaçam, em que a miséria sobe tão alto que ofende com o seu clamor a conciencia dos ricos e poderosos, aparece, no cenário da historia, o vulto da reação, sacudindo sobre a estatua da liberdade a culpa do desajustamento.

O programa do FACISMO, NAZISMO E, PORTANTO, INTEGRALISMO, é a ditadura. A força é o seu programa.

São partidos anti-democráticos que procuram usar de uma liberdade da qual não deviam usar, porque são inimigos da liberdade, erguem-se dentro da terra bradando contra nós, contra nosso programa belo de ação.

Nada mais anti-cristão do que facismo e suas congêneres.

A filosofia da força contra a meiguice das palavras humanitárias de Cristo. Enquanto Jesus pregou o AMOR AO PROXIMO COMO A VÓS MESMO, - grita o facismo, de Cia dos canhões, que "mais vale ser leão um dia do que ovelha um ano". O nazismo, com a sua palavra de terror, vem levantando uma campanha terrivel e injustificável contra a Religião Católica.

\footnotetext{
${ }^{34}$ Para pensar... O Mensageiro. Garanhuns, 15 de maio de 1937, p. 1 - APEJE.
} 
O integralismo, entre nós, se dizendo espiritualista, ostentando uma falsa religiosidade, aproxima-se da Egreja Católica, num paíz essencialmente Católico, para obter por seu intermédio, o apoio e simpatia do povo.

Os integralistas carragando os andores das procissões, os integralistas mandando celebrar Missas em ações de graças por terem sido soltos seus camaradas extremistas.

Porém, queira conhecer de perto a maioria das cabeças integralistas saberá julgar a sua religiosidade. ${ }^{35}$

$\mathrm{Na}$ confrontação entre esses dois artigos, encontra-se uma tentativa de inversão dos sentidos dos discursos pronunciados pelos integralistas. Os jornalistas maçons de Garanhuns colocavam-se como membros de uma instituição que coexistiu durante séculos em vários países, mas que sempre estiveram ao lado da liberdade e da democracia. O argumento presente na citação anterior pautou-se em apresentar os maçons como perseguidos em todos os países com sistemas ditatoriais, independentemente se esquerda ou direita, como nos casos da Rússia, Alemanha, Itália e Portugal. Com essa observação, os membros da loja Mensageiros do Bem procuravam colocar-se ao lado da democracia brasileira.

Na segunda citação, o autor colocou lado a lado fascistas, nazistas e integralistas. Por meio dessa comparação, os maçons de Garanhuns procuravam atacar o que os camisas-verdes consideravam ser seus pilares doutrinários, no caso, seu caráter nacionalista e espiritualista. Lembrando que no segundo semestre de 1937, as disputas eleitorais se intensificavam, ao comparar o integralismo com os movimentos de extrema direita europeia, o jornalista maçônico tinha a intenção não apenas de chamar a AIB de uma imitação, mas de torna-la uma ameaça ao sistema democrático que o Brasil vivenciava naquele momento. $\mathrm{O}$ poder exercido por esses políticos aos moldes fascistas foi descrito por esse jornalista a partir da supressão da liberdade democrática e da imposição da força que iria de encontro aos preceitos de fraternidade defendidos pelo cristianismo. Mesmo que os partidos do velho mundo fincassem seu posicionamento frente à religião Católica, os integralistas ainda tentavam

\footnotetext{
${ }^{35} \mathrm{O}$ fascismo, o nazismo e o integralismo. O Mensageiro. Garanhuns, 15 de maio de 1937, p. 3-4 - APEJE.
} 
utilizar-se dessa instituição para alcançar os brasileiros que, em sua maioria, comungavam desse credo. No entanto, o jornalista maçom chamava a atenção para o fato de que depois de conhecer pessoalmente os militantes da AIB, as máscaras caíam e o fervor religioso não passaria de demagogia.

Alberto Rêgo, em seu livro de memórias sobre a Garanhuns dos anos 1930, elaborou um mapeamento dos garanhuenses com quem conviveu nas primeiras décadas do século XX. Contribuindo, em certo momento de sua obra, para uma compreensão da importância política, intelectual e econômica dos maçons no município. Ele destacou que tanto o seu pai, Dario Rêgo (Grão-Mestre da Maçonaria), que nos idos de 1930 tornou-se proprietário do Diário de Garanhuns, como os outros maçons da cidade eram homens respeitados e com estreitos laços de amizade com o clero da Diocese de Garanhuns e com famílias tradicionais da região. Sendo os maçons apresentados por esse autor como católicos fiéis aos ensinamentos da Igreja. Além de serem empresários e políticos importantes da região. ${ }^{36}$

Sabendo da importância de serem associados ao cristianismo, principalmente em uma cidade marcada pelo catolicismo, os membros do corpo editorial procuraram associar suas imagens aos ensinamentos da Igreja Católica, como se percebe no seguinte trecho de um de seus dos artigos de $O$ Mensageiro.

Porque não temos dinheiro

A despeito da pujança da Maçonaria em todo o globo terráqueo, sem embargo da solidariedade que une os seus membros afasadas as questões de limites territóriais, de raça e de línguas, a instituição da Maçonaria vive pobremente, dentro do exemplo eloquente do Divino Mestre, tão postergado por quanto lhe querem imitar os exemplos e pregar as suas palavras. [...]

É que todo o nosso dinheiro ainda é pouco para distribuirmos aos que, necessitados, morrem sem remédio, sem pão e sem conforto. $[\ldots]$

\footnotetext{
${ }^{36}$ RÊGO, Alberto da Silva. Os aldeões de Garanhuns, sua gente, seus jovens, suas associações, o mundo literário, os "players", os poetas, e árvores genealógicas. Recife: FIAM/ Centro de Estudos de História Municipal, 1987, p. 211-212.
} 
O nosso intuito é dar pão a quem tem fome e dar água a quem tem sêde, sem que quem coma ou beba não sinta a humilhação da publicidade. ${ }^{37}$

A pretensão de criar uma imagem baseada na compaixão e na caridade foi uma constante entre os membros desse jornal. Nessa citação, somando-se aos valores cristãos, percebe-se também um interdiscurso ${ }^{38}$ com o evangelho de Mateus, quando narra uma das pregações de Jesus Cristo, em que Ele teria dito: "dar o pão a quem tem fome, a água a quem tem sede, acolher o estrangeiro, vestir o nu, visitar o doente e o preso." 39 Nesse tipo de relação criada entre dois discursos de origens distintas, o enunciado atual busca no anterior os alicerces de sua autoridade, criando sentidos e legitimidades entre os ouvintes e/ou leitores desses jornais, pois os argumentos estavam coerentes com um já-dito. ${ }^{40}$

Entre os meses de julho e agosto de 1937, Heli Leitão escreveu quatro artigos com o título: Notas em torno do "manifesto-programa" para o jornal O Mensageiro, nos quais procurou deslegitimar o programa integralista para a presidência do país. $\mathrm{Na}$ análise desse documento, esse jornalista descreveu que os planos da AIB de uma democracia corporativa, em sua interpretação, não passaria de Estado ditatorial. Na segunda publicação dessa coluna, Leitão escreveu:

\footnotetext{
${ }^{37}$ Porque não temos dinheiro. O Monitor, Garanhuns, 13 de junho de 1937, p. 1 - APEJE.

${ }^{38}$ Para os analistas do discurso Dominique Maingueneau e Patrick Charaudeau, o interdiscurso pode ser entendido como: "[...] chama-se também de "interdiscurso" o conjunto das unidades discursivas (que pertencem a discursos anteriores do mesmo gênero, de discursos contemporâneos de outros gêneros etc.) com os quais um discurso particular entra em relação implícita e explícita. Esse interdiscurso pode dizer respeito a unidades discursivas de dimensões muito variáveis: uma definição de dicionário, uma estrofe de um poema, um romance... CHARAUDEAU, Patrick. \& MAINGUENEAU, Dominique. Dicionário de Análise do Discurso. São Paulo: Contexto, 2008, p. 286.

${ }^{39}$ Português. Bíblia Sagrada. Tradução por João Ferreira de Almeida. Barueri - SP: Sociedade Bíblica do Brasil, 1993. 1408 p. Mateus 25: 31-46.

${ }^{40} \mathrm{O}$ termo já-dito aparece na obra Arqueologia do Saber de Michel Foucault em um momento em que o autor desenvolve uma discussão que continua em outra obra sua, chamada $O$ que é um autor?. No caso, Foucault começou a analisar como as produções textuais de livros formam-se a partir de diálogos sutis com outros textos produzidos anteriormente, mantendo assim um interdiscurso. O já-dito seria então um deslocamento de sentido de discursos pretéritos a um momento posterior que busca na aceitação de verdade do que o precedeu um lugar de produção e legitimidade. Nesse caso, não deixa de destacar que um discurso não surge do nada, mas precisa das condições necessárias para serem reproduzidas e aceitas. FOUCAULT, Michel. A arqueologia do saber. Rio de Janeiro: Forense Universitária, 2002, p. 28. Veja também: O que é um autor? Lisboa: 2009, p. 29-87.
} 
Uma campanha política para uma eleição que não aconteceu: as práticas ...

Aliás, os que discordam do integralismo não o fazem por acharem más as realizações que pretende. Seria necedade ou mesmo injustiça grosseira negar que o integralismo realiza uma campanha disciplinada tanto ou quanto interessada em tornar o Brasil uma potencia entre as nações do Continente e do Mundo. Mas o espirito, a essência do integralismo, cheira à fascismo, embora essa verdade claríssima seja negada por todos os adeptos do sr. Plinio Salgado. Adotar no Brasil um governo totalitário, centralista; enquadrar toda a engrenagem moral e social nessa bitola de compressão nessa estrutura de forma, é que ano entra nas cabeças de mais de quarenta milhões de brasileiros. ${ }^{41}$

Durante a corrida pela presidência do país, os jornalistas de O Mensageiro, a exemplo do Diário de Garanhuns, escolheram para apoiar a candidatura de José Américo de Almeida, organizando comícios pelas ruas da cidade, como o ocorrido em 26 de julho de 1937. Em paralelo à campanha do nome desse candidato para a presidência, ambos os jornais procuraram deslegitimar a argumentação de que o comunismo estava à espreita para voltar ao cenário político com as eleições, que esse tipo de discurso foi utilizado pelos integralistas apenas para implantar a sensação de medo entre os brasileiros. Como aparece no seguinte artigo:

QUE FORÇA DE EXPRESSÃO!...

O sr. Plínio Salgado manda seus adeptos praticar arruaças, e, depois, porque não surtiu o efeito desejado, ocupa o microfone de um rádio e com voz fanhosa insulta todos os brasileiros que não acompanham na grande comedia verde. Para ele e todos os seus obsecados seguidores o Brasil transformou-se em uma grande arena comunista; Armando de Sales, José Américo, Deputados Senadores, Ministros, Intelectuais, Industriais, Comerciantes, Empregados, o povo e até Juízes são comunistas. E porque não vestem uma camisa verde, não escaparam nem os simpatizantes que estão de braços cruzados, na posição dos que pescam, esperando que o peixe seja iscado. Assim se expressou o grande "chefe" e "salvador": "Serão implacavelmente castigados aqueles que não participarem da revolução verde e, ao contrario ficarem de braços cruzados”. Que grande nacionalidade!? Que extraordinário pacifista!? É muita força de expressão não há duvida mas esses podem provocar histérico em alguns mocinhos

${ }^{41}$ Notas em torno do "Manifesto-Programa" II. O Mensageiro. Garanhuns, 25 de julho de 1937, p. 1 - APEJE. 
que, com um geitão todo deles, envergam a camisa verde, porém nunca aos brasileiros dignos deste nome. Fiquem certos todos os sigmaticos, que em nossa Pátria nem facismo nem comunismo conseguirão implantar o regime do nó da peia. O Brasil conseguiu ser. É e será sempre dos brasileiros. ${ }^{42}$

O sentimento de medo construído em torno da imagem do comunismo tornou-se uma das principais estratégias discursivas dos integralistas. Nesse sentido, se os adversários quisessem frear o crescimento da AIB e deslegitimar seus discursos, tinham de desconstruir esse clima de tensão causado pelo temor de um golpe comunista. Em um "tom jocoso", o jornalista d'O Mensageiro procurou questionar as propostas e postura do lider da AIB e seus seguidores, colocando neles a culpa em organizar desordens sociais e depois criar histórias que culpavam os comunistas. Estes inimigos "vermelhos" no discurso integralista, segundo esse jornalista maçom e outros que contribuíam para o referido jornal da cidade, não passavam de bodes expiatórios para os atos de vandalismo dos próprios camisas-verdes.

No entanto, a tensão entre os maçons e integralistas de Garanhuns chegou ao enfrentamento em espaço público durante as festividades de 07 de Setembro, quando a loja maçônica Mensageiro do Bem financiou um almoço e jogos para comemorar a Independência do Brasil. A partir desse momento, intelectuais, políticos e autoridades policiais começaram a figurar nas páginas dos jornais do município, envolvidos na confusão que marcou a referida festa civica. O clima de perseguição e vigilância policial marcou então os meses que antecederam a implantação do Estado Novo no município.

\section{Integralistas versus maçons em Garanhuns: a festa de Independência do Brasil em 1937 como palco de batalha}

Como os integralistas apresentavam-se no lugar social de defensores da nacionalidade brasileira, as festas cívicas eram circunstâncias em que eles procuravam atuar e mostrar o seu amor e respeito aos que consideravam heróis da pátria e simbolos nacionais. Nesse caso, as comemorações em torno do dia

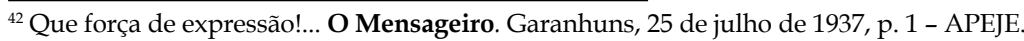


07 de Setembro em 1937, festa da Independência do Brasil em relação ao domínio colonial de Portugal, foi o momento em que, nas ruas da cidade as tensões entre os camisas-verdes e os opositores políticos e força policial se intensificaram.

Nesse dia, a festa cívica foi vivenciada com a bandeira desfraldada a meio mastro por problemas técnicos, fato sarcasticamente comentado pelos integralistas: "É que por uma ironia do cego destino esta coincidência tinha sua razão de ser: o sr. secretário da Prefeitura anuncia oficialmente os oradores[...]" ${ }^{43}$ E um dos palestrantes: "[...] era um jovem sem Deus, Sem Pátria, sem Família[...] E nisto a razão do protesto mudo do Pavilhão Nacional." ${ }^{44}$ Esse jovem era o Eurico Costa, bacharel em direito.

Enquanto ocorria essa comemoração, financiada pela loja maçônica da cidade, e o jovem Eurico Costa começava seu discurso, o camisa-verde José Rodrigues Silva, vulgo José Batatinha, interrompia, aos gritos, o pronunciamento do orador, acusando-o de comunista e inimigo da pátria. Em represália, o comissário Manoel Barbosa da Delegacia de Ordem Política Social (DOPS) tentou impedir Batatinha, que não se conteve e por isso acabou preso por desacato à autoridade. Não sendo essa a última vez que esse integralista seria detido. Esse fato levou à mobilização dos militantes do núcleo, que começaram a questionar as intenções desse comissário. No mesmo dia, o Chefe Municipal da AIB, Mario Matos, enviou vários telegramas para a liderança do movimento, para autoridades políticas e para a imprensa da capital pernambucana.

Dois dias depois, 09 do corrente mês, esses telegramas foram publicados na primeira página do jornal $A$ Razão. Neles era demonstrada a indignação do chefe municipal que se pautava no fato de um nacionalista, como o integralista José Batatinha, ser preso por combater um indivíduo, que segundo Matos, era fichado na DOPS-PE no Recife como comunista. Dessa forma, o primeiro telegrama foi enviado para a residência de $\mathrm{n}^{\circ} 51$, na Rua Quintanda - Rio de Janeiro, e direcionada a Plínio Salgado. Nesse comunicado, a autoridade policial, que

\footnotetext{
${ }^{43}$ A semana da Pátria. A Razão. Garanhuns, 12 de setembro de 1937, p. 4 - APEJE.

${ }^{44}$ Ibidem.
} 
efetuou a prisão do integralista, foi apontada como "[...] membro relevante loja maçônica local, animador festas tiveram referido comunista orador oficial." ${ }^{45}$ Além de comunicar também ao chefe provincial da AIB e ao então governador do estado de Pernambuco, Carlos de Lima Cavalcanti. Para Mario Matos, o teor comunista do discurso do Eurico Costa teria sido a justificativa da ação do integralista garanhuense, repreendida pelo comissário, que participava dessa festa, financiada pela loja maçônica local e com a presença do deputado Mario Lira e do prefeito Thomaz Maia. Ao associar esses políticos e o policial Manoel Barbosa à maçonaria - uma das forças consideradas inimigas da nacionalidade brasileira, chegando a ter todas as suas lojas fechadas no final de outubro de 1937 -, o intuito era deslegitimar a ação desses contra a AIB. Somando-se a isso, havia o fato de esses importantes membros da sociedade garanhuense apoiarem o nome de José Américo de Almeida, em detrimento dos outros candidatos, principalmente Salgado. O Chefe Municipal da AIB escreveu ao governador Lima Cavalcanti o seguinte: "Diante disto testemunhamos perante vocencia repulsa tão claras demonstrações gravidade situação e protestamos indignados circunstancia ter sido designado orador oficial cerimônia de hoje mesmo comunista hontem tão claro se manifestou." ${ }^{46}$

No mesmo dia do incidente, o referido comissário enviou à Secretaria da Segurança Pública, com sede no Recife, um relatório sobre o fato. Nesse informe, destacou que na manhã do dia 07 de setembro, quando na cidade se comemorava o dia da independência do país, um grupo de integralistas perturbava a ordem pública. No decorrer das comemorações, quando o acadêmico Eurico Costa atacou em seu discurso o integralismo, mas segundo o relatório sem ferir as normas legais do estado democrático, foi então rechaçado pelos camisas-verdes presentes. No intuito de impedir que os ânimos se exaltassem ainda mais, segundo o comissário, ele tentou controlar a ação dos membros da AIB.

No trecho do relatório que descreve o momento em que a autoridade policial se dirigiu aos integralistas, um deles acabou

${ }^{45}$ Telegramas. A Razão. Garanhuns, 09 de setembro de 1937, p. 1 - APEJE (Grifo nosso).

${ }^{46}$ Ibidem. 
agindo da seguinte forma:

Dirigi-me a José Batatinha pedindo-lhe que se acalmasse, sendo eu neste momento recebido desatenciosamente pelo mesmo, tendo o José Batatinha, me tachado de communista, pelo que dei-lhe vós de prisão, mandando-o recolher à Delegacia.

Esta medida deu resultado satisfatório, pois contribuio para que os demais se retirassem do local da festa. ${ }^{47}$

Nesse fragmento do relatório, além de causar desordem durante a festa cívica, o integralista José Batatinha tinha desacatado a autoridade do comissário Manoel Barbosa chamando -o de comunista. Por esse motivo, o referido camisa-verde teria sido preso e a ordem social reinstituída na cidade. No exemplar de 12 de setembro de 1937 do jornal A Razão, o chefe municipal Mario Matos ainda traçou algumas críticas ao referido comissário, que além dos acontecimentos citados até agora, esse policial teria dificultado, o máximo possivel, o desenvolvimento das atividades do núcleo integralista no município, principalmente no centro da cidade, onde residia a maior parte dos camisasverdes. A reclamação se dava por causa da vigilância exercida sobre os principais nomes do movimento em Garanhuns, postura infundada para Mario Matos, pois: “[...] não há dentre os integralistas que ocupam postos salientes no Núcleo de Garanhuns um só que mereça a vigilância da policia como agitador, como detrator, como elemento perigoso à sociedade e consequentemente à ordem pública." ${ }^{48}$ Levantar suspeitas sobre as intenções do Delegado tinha a intenção de legitimar a ideia de que os militantes da AIB estavam sofrendo com as perseguições de seus inimigos políticos locais (comunistas e maçons).

Um dos atos de controle policial, visto como desnecessário pelos integralistas, foi a exigência de que todas as atividades e cerimônias efetuadas pelo núcleo, antes de serem realizadas, deveriam ser comunicadas por escrito à autoridade policial, informando os objetivos e, caso saísse às ruas, qual seria o percurso a ser seguido. $O$ fato de serem tratados como desordeiros pelo representante da polícia local levou os integralistas a questionarem o motivo de tamanho controle sobre as ações do

\footnotetext{
${ }_{47}$ Relatório policial. Prontuário funcional $\mathbf{n}^{\mathbf{0}} 1027$. DOPS-PE/APEJE.

${ }^{48}$ Partidarismo Injustificável. A Razão. Garanhuns, 12 de setembro de 1937, p. 1 - APEJE.
} 
movimento, chegando à seguinte conclusão sobre as intenções do Comissário: "Só uma elevada dose de má fé pode justificar a interpretação do sr. Comissário. Aliás, essa interpretação não me surpreende, uma vez que o sr. Comissário a mim mesmo já dissera, certa vez, que era 'maçon, anti-integralista e aos integralistas só dava o mínimo que a lei permitia[...]"'49

No desenvolver desse mesmo artigo, essa antipatia à AIB do Comissário se fazia sentir também nos Cafés da cidade, onde ele tecia cotidianamente comentários desfavoráveis à AIB e tratava de maneira áspera os militantes desse partido político. Além disso, esse também foi apresentado como um dos principais animadores de um jornal maçônico na cidade, no caso $O$ Mensageiro, que além de Dário Rêgo, proprietário do Diário de Garanhuns, também era associado à loja maçônica $O$ Mensageiro do Bem. Dessa forma, dois periódicos ofereciam espaços para os inimigos dos integralistas exporem suas ideias sobre o cenário político nacional e combater a expansão da doutrina do Sigma na região.

No entanto, contrariando as expectativas dos integralistas que esperavam sair vitoriosos das disputas nas urnas, esses militantes acabaram amargando a ilegalidade com a implantação do Estado Novo (1937-1945). A partir dessa reformulação do cenário político, os camisas-verdes vivenciaram o processo de passagem da imagem de seu partido, que deixava de figurar enquanto defensor dos pilares nacionais e religiosos para a situação de subversivo e subserviente aos governos de extrema direita europeia. Em Garanhuns, os seguidores de Salgado amargaram um ostracismo político com o novo regime político de Vargas, levando muitos de seus líderes, como o José Batatinha, a fugirem da cidade, por medo de represália policial e de populares.

\section{Considerações finais}

Ao elaborar esse trabalho, observamos que o propósito de tecer algumas considerações sobre as discussões travadas no decorrer desta pesquisa não é de encerrar as possibilidades

\footnotetext{
${ }^{49}$ Ibidem.
} 
de fazer mais abordagem sobre o tema, mas retomar algumas questões e, a partir delas, promover, aos leitores, condições para realizarem outras perspectivas acerca do tema. Como norte, tivemos o cotidiano politico da cidade de Garanhuns no decorrer das disputas eleitorais de 1936 e 1937, dando atenção especial às atividades dos militantes do núcleo integralista local.

Nos anos correspondentes à legalidade política, os integralistas produziram discursos que possuíam como uma das principais características, o maniqueísmo, em que as forças do bem (integralismo) encontravam-se incessantemente envolvidas em conflitos contra o mal, representado por seus opositores. A construção da imagem desse inimigo da AIB dependia dos interesses dos que pronunciavam e recebiam os discursos doutrinários, podendo ser apresentado no comunismo, liberalismo, judaísmo e na maçonaria. Esses inimigos não eram apenas dos integralistas, mas apontados como um perigo à ordem social e política do país. Dessa forma, o medo criado em torno de supostas ameaças à pátria assumia uma função primordial no processo de doutrinação da AIB. Com a aproximação da eleição presidencial, marcada para 03 de janeiro de 1938, as disputas politicas em Garanhuns refletiam o que se passava em todo o país. Os partidários dos candidatos que se lançaram à presidência do país começaram a disputar os votos dos eleitores. O integralismo lançou o nome de Plínio Salgado, que fez frente a Armando Sales de Oliveira e José Américo de Almeida, candidatos dos partidos liberais. No município estudado, os correligionários do candidato Almeida, muitos deles membros da loja maçônica $O$ Mensageiro do Bem, foram aqueles que tiveram maior atuação contra os integralistas.

Enfim, durante a pesquisa, tentamos perceber como o discurso de ameaça comunista foi utilizado para a construção de um lugar de defensor da pátria e dos pilares religiosos para os integralistas de Garanhuns no decorrer das eleições de 193637. Procurando, assim, compreender as condições de funcionamento do ensinamento integralista na sociedade garanhuense dos anos 1930. Entretanto, não tivemos como escopo expor respostas definitivas sobre o assunto aqui discutido, mas tivemos a intenção de possibilitar, a partir de nossa escrita, novas abordagens sobre o integralismo e proporcionar debates futuros. 
Resumo: Nesse artigo discutiremos o envolvimento dos militantes da Ação Integralista Brasileira (AIB) no município de Garanhuns, no agreste pernambucano, durante a campanha presidencial de Plínio Salgado. O processo de construção da imagem pública de um candidato vai ser nossa principal meta. Para isso, analisaremos o jornal do núcleo da AIB local, intitulado de $A$ Razão, meio pelo qual as propostas políticas desse grupo foram divulgadas aos leitores do referido periódico, entre os anos de 1936 e 1937. No entanto, as práticas propagandísticas dos integralistas na cidade não se deram sem a presença de uma oposição, conferimos uma atenção especial aos membros da loja maçonica $O$ Mensageiro do Bem, que desempenharam uma ferrenha campanha de oposição à candidatura do líder da AIB, apoiando, em contrapartida, o nome do então presidenciável José Américo de Almeida. Desse modo, buscaremos analisar como uma campanha política de âmbito nacional, igual à de Salgado, interferiu no cotidiano desta cidade do interior pernambucano.

Palavras-chave: Ação Integralista Brasileira. Garanhuns. Campanha presidencial. Loja maçônica.

Abstract: In this article we will discuss the involvement of militants Ação Integralista Brasileira (AIB) in the municipality of Garanhuns, in rural Pernambuco, during the presidential campaign Plinio Salgado. The process of building the public image of a candidate will be our main goal. For this, we analyze the newspaper's core AIB site, titled $A$ Razão, means by which the policy proposals of this group have been disclosed to readers of this journal between the years 1936 and 1937. However, the practices of fundamentalist propaganda in the city did not occur without the presence of an opposition, among them, give special attention to members of the Masonic Lodge of $O$ Mensageiro do Bem, they played a fierce campaign against the candidacy of the leader AIB, supporting counterpart in the name of then-presidential candidate José Américo de Almeida. Thus, we try to analyze how a national political campaign, like Salgado, interfered in everyday life in this town in Pernambuco.

Keywords: Ação Integralista Brasileira. Garanhuns. Presidential campaign. Masonic lodge.

Artigo recebido para publicação em 06/08/2012

Artigo aprovado para publicação em 10/12/2012 